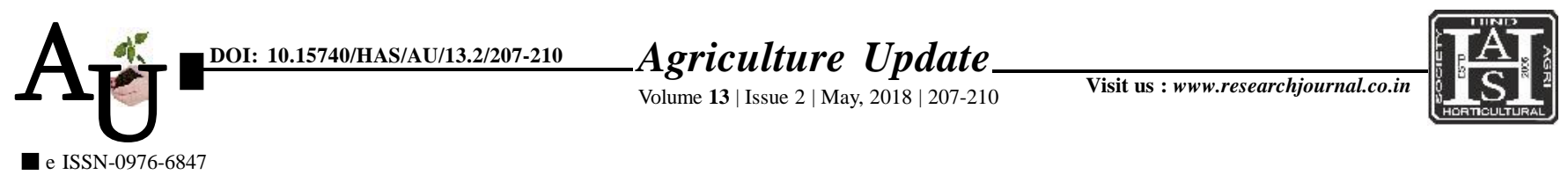

\title{
Research Article: Association between selected independent variables and adoption of moth interventions by the respondents
}

\section{Ramdhan Ghaswa, S.K. Sharma, S.S. Bana and Amit Kumar}

Article Chronicle : Received : 22.02.2018;

Revised : 04.04.2018; Accepted : 17.04.2018

\section{Key Words :}

Adoption, Association, Variables, Moth interventions, Respondents

Author for correspondence :

Ramdhan Ghaswa Directorate of Extension Education, S.K. Rajasthan Agricultural University, Bikaner (Rajasthan) India

Email:ghaswaextension@ gmail.com

See end of the article for authors' affiliations
SUMMARY : The present study was conducted in Bikaner district of Rajasthan. The National Food Security Mission is in operation in all six Panchayat Samities of Bikaner district. Out of which fifty per cent Panchayat Samities, i.e. three Panchayat Samities Nokha, Lunkarnshar, Sri Dungargarh were selected purposely. Out of selected Panchayat Samities three Gram Panchayats were selected randomly from each Panchayat Samities on the basis of random sampling method. Thus, the total 9 villages were selected. To know the impact of National Food Security Mission, a control group of villages was also be required. Therefore, three distant villages where the National Food Security Mission was not in operation were also selected on the basis of random sampling technique from each identified Panchayat Samiti. 7 beneficiary and 7 non-beneficiary Gram respondents were selected randomly from each identified village. Thus, a total of 63 beneficiary respondents and 63 non-beneficiary Gram respondents were selected. It was found that personal characteristics viz., age and economic motivation were not significantly associated with adoption of recommended interventions of moth. Education, size of land holding, income level, cosmopoliteness and extension contact were significantly associated with adoption of recommended interventions of moth. It means that there was significant effect of these personal variables on adoption of recommended interventions of moth.

How to cite this article : Ghaswa, Ramdhan, Sharma, S.K., Bana, S.S. and Kumar, Amit (2018). Association between selected independent variables and adoption of moth interventions by the respondents. Agric. Update, 13(2): 207-210; DOI : 10.15740/HAS/AU/13.2/207-210. Copyright@ 2018: Hind Agri-Horticultural Society. 